\title{
PEMANFAATAN FUSI DATA SATELIT LAPAN-A3/IPB DAN LANDSAT 8 UNTUK MONITORING LAHAN SAWAH
}

\section{Development of Data Fusion Utilization Model for LAPAN-A3/LAPAN-IPB Satellite and Land- sat 8 for Paddy Field Monitoring}

Yudi Setiawan ${ }^{\mathrm{a}, \mathrm{c}}$, Lilik Budi Prasetyo ${ }^{\mathrm{a}}$, Hidayat Pawitan ${ }^{\mathrm{b}}$, Liyantono ${ }^{\mathrm{d}}$, Syartinilia ${ }^{\mathrm{e}}$, Arif Kurnia Wijayanto $^{\mathrm{c}}$, Prita Ayu Permatasaric ${ }^{\mathrm{c}}$, A Hadi Syafrudin ${ }^{\mathrm{f}}$, Patria Rachman Hakim ${ }^{\mathrm{f}}$

a Departemen Konservasi Sumberdaya Hutan dan Ekowisata, Fakultas Kehutanan, Institut Pertanian Bogor, Kampus IPB Darmaga, Bogor 16680 — setiawan.yudi@apps.ipb.ac.id

${ }^{\mathrm{b}}$ Departemen Geofisika dan Meteorologi, Fakultas Matematika dan Ilmu Pengetahuan Alam, Institut Pertanian Bogor, Kampus IPB Darmaga, Bogor 16680

${ }^{\mathrm{c}}$ Pusat Penelitian Lingkungan Hidup, Lembaga Penelitian dan Pengembangan kepada Masyarakat (PPLHLPPM), Institut Pertanian Bogor, Kampus IPB Darmaga, Bogor 16680

d Departemen Teknik Mesin dan Biosistem, Fakultas Teknologi Pertanian,, Institut Pertanian Bogor, Kampus IPB Darmaga, Bogor 16680

${ }^{e}$ Departemen Arsitektur Lanskap, Fakultas Pertanian, Institut Pertanian Bogor, Kampus IPB Darmaga, Bogor 16680

${ }^{f}$ Pusat Teknologi Satelit, Lembaga Antariksa dan Penerbangan Nasional (LAPAN), Jl. Cagak Satelit, Rancabungur, km 104, Bogor 16310

\begin{abstract}
Increasing of economic development is generally followed by the change of landuse from agriculture to other function. If it occurs in large frequency and amount, it will threaten national food security. Therefore, it is necessary to monitor the agricultural land, especially paddy fields regarding to changes in landuse and global climate. Utilization and development of satellite technology is necessary to provide more accurate and independent database for agricultural land monitoring, especially paddy fields. This study aims to develop a utilization model for LAPAN-IPB satellite (LISAT) and other several satellites data that have been used for paddy field monitoring. This research is conducted through 2 stages: 1) Characterization LISAT satellite data to know spectral variation of paddy field, and 2) Development method of LISAT data fusion with other satellites for paddy field mapping. Based on the research results, the characteristics Red and NIR band in LISAT data imagery have a good correlation with Red and NIR band in LANDSAT 8 OLI data imagery, especially to detect paddy field in the vegetative phase, compared to other bands. Observation and measurement of spectral values using spectroradiometer need to be conducted periodically (starting from first planting season) to know the dynamics of the change related to the growth phase of paddy in paddy field. Pre-processing of image data needs to be conducted to obtain better LISAT data characterization results. Furthermore, it is necessary to develop appropriate algorithms or methods for geometric correction as well as atmospheric correction of LISAT data.
\end{abstract}

Keywords: Climate change, LAPAN-A3/LAPAN-IPB, paddy field monitoring, satellite

(Diterima: 01-12-2017; Disetujui: 24-01-2018)

\section{Pendahuluan}

\subsection{Latar Belakang}

Pertambahan jumlah penduduk yang tinggi akan mendorong meningkatnya permintaan pangan dan sumberdaya alam (Agus, 2014). Laju pertumbuhan penduduk Indonesia yang diperkirakan sekitar 1,3 - 1,5 persen pertahun tentulah harus diimbangi dengan pemenuhan kebutuhan pangan, sehingga angka pertumbuhan produksi pangan seharusnya di atas atau setidaktidaknya sama dengan angka laju pertumbuhan penduduk tersebut. Upaya pemenuhan kebutuhan pangan tersebut dapat terwujud salahsatunya dengan adanya dukungan ketersediaan lahan pertanian. Informasi terkait ketersediaan lahan pertanian ini haruslah dapat diperoleh dan dikelola secara cepat dan akurat.
Monitoring lahan sawah di Indonesia, khususnya Pulau Jawa, secara kontinu menggunakan teknologi remote sensing dapat memberikan informasi dinamika perubahan tutupan lahan (pola tanam) di lahan sawah, seperti: (1) padi, lahan-bera, palawija, (2) padi, lahanbera, lahan-digenangi, padi, lahan-bera, palawija, dan (3) padi, lahan-bera, lahan-digenangi, padi, lahan-bera, lahan-digenangi, padi. Dinamika perubahan pola tanam ini dapat terjadi dari tahun ke tahun mengikuti kondisi iklim dan karakteristik lahan (Setiawan et al., 2014; Setiawan dan Yoshino, 2013).

Saat ini, sebagian besar informasi yang tersedia terkait lahan sawah masih sangat terbatas. Pengembangan teknologi satelit sangat diperlukan untuk menyediakan data dasar yang lebih akurat dan mandiri bagi pemantauan sumberdaya alam dan lingkungan, termasuk lahan pertanian semusim, terutama padi, yang dapat difokuskan pada perolehan informasi berbagai 
fase pertumbuhan padi serta estimasi luasan panen atau awal musim tanam.

Untuk mengembangkan teknologi satelit dan pemanfaatan data satelit untuk ketahanan pangan di Indonesia, LAPAN dan IPB melahirkan kesepakatan untuk mengembangkan dan meluncurkan satelit LAPAN-IPB (LAPAN-IPB Satellite/LISAT atau LAPAN-A3) untuk mendukung ketahanan pangan dan monitoring lingkungan di Indonesia. Satelit LISAT ini mengemban tugas yang sangat kompleks sebagai sistem observasi bumi operasional pertama yang dikembangkan oleh tenaga ahli Indonesia.

Untuk itu, IPB akan dan terus melakukan berbagai penelitian terkait pengembangan algoritma satelit termasuk pengembangan model kalibrasi silang, koreksi atmosfer dan radiometric serta penelitian aplikasi dan pemanfaatan data satelit khususnya di bidang pertanian.

\subsection{Tujuan}

Penelitian ini bertujuan untuk mengembangkan model pemanfaatan kombinasi data satelit LAPANIPB dan data beberapa satelit lain yang telah lama dipergunakan untuk melakukan pemantauan lahan sawah, termasuk dinamika perubahan yang terjadi didalamnya.
Pengamatan lahan pertanian secara terus menerus melalui teknologi remote sensing ini sangat fundamental dalam mengidentifikasi fase pertumbuhan dan intensitas tanam padi sawah, termasuk perubahan pola pertumbuhan (plant stress) yang diakibatkan oleh faktor lingkungan, seperti kekeringan.

\section{Metode}

\subsection{Waktu dan Tempat}

Penelitian lapang dilakukan di lahan sawah sekitar wilayah pantai utara Jawa, Kabupaten Karawang, Jawa Barat (Gambar 1). Pada tahap penelitian tahun ke-1, observasi lapangan dilakukan pada bulan Juni hingga September 2017, yang merupakan musim tanam ke III. Analisis data citra satelit dilakukan di LISAT Data Center IPB, PPLH-IPB dan di Laboratorium Database Spatial dan Analisis Lingkungan, Fakultas Kehutanan, IPB.

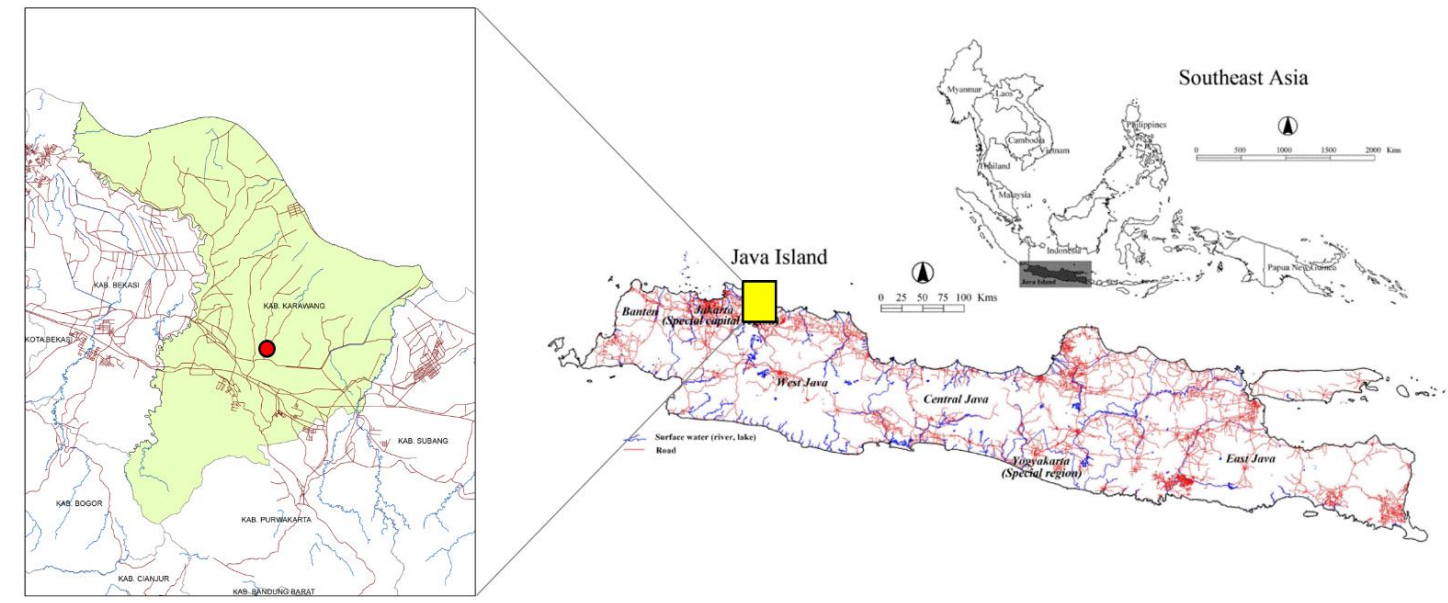

Gambar 1. Lokasi studi di Kabupaten Karawang, Jawa Barat

\subsection{Alat dan Bahan}

Dalam kajian ini, data satelit LAPAN A3/IPB digunakan untuk menganalisis fase tanam padi di lahan sawah. Data citra LAPAN-A3/IPB berukuran $130 \mathrm{x}$ $200 \mathrm{~km}$ dengan waktu akuisisi pada tanggal 17 Juni 2017 diperoleh dari LISAT Data Order System (LDOS) IPB. Selain itu, data citra satelit dengan resolusi yang mendekati spesifikasi LAPAN A3/IPB, yaitu LANDSAT, dipergunakan untuk menilai karakteristik spectral dari sensor yang digunakan. Data citra LANDSAT 8 yang dipergunakan merupakan data yang diakuisisi pada tanggal 19 Juni 2017, berdekatan dengan data satelit LAPAN-A3/IPB.

Selain data citra satelit, data citra resolusi tinggi yang diambil menggunakan quadcopter drone yang dilengkapi dengan kamera RGB dan kamera multispectral Parrot Sequoia digunakan sebagai referensi dalam membedakan tahap pertanaman lahan sawah dan pemilihan lokasi sampling. Data citra ini memiliki resolusi spasial sekitar 5-7 cm/piksel (Gambar 2).

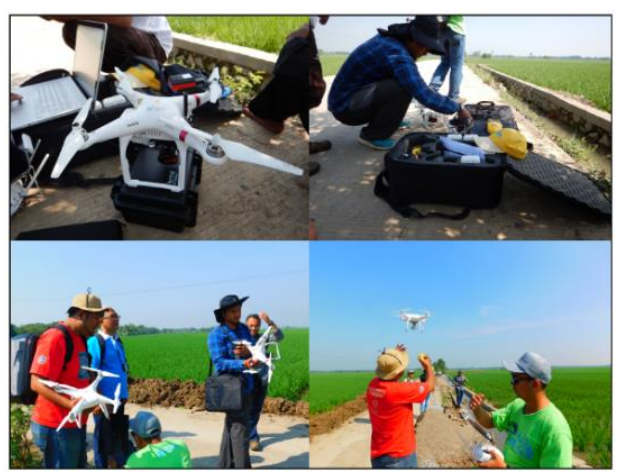

Gambar 2. Persiapan dan pengambilan data citra dengan quadcopter drone 
Selain pengambilan data citra menggunakan quadcopter drone, dilakukan pula pengukuran nilai reflectance dari tanaman padi menggunakan spectroradiometer. Pengukuran ini dilakukan untuk memperoleh data referensi pada beberapa fase pertumbuhan padi (Gambar 3).

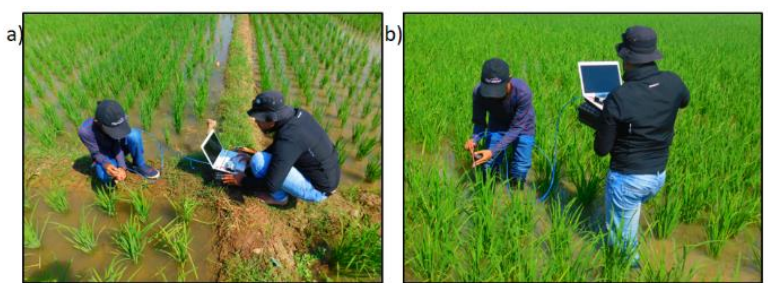

Gambar 3. Pengukuran nilai reflectance tanaman padi dengan menggunakan spectroradiometer a) umur 3 MST, b) umur 5 MST

Data hasil kunjungan lapang (field survey) dilakukan untuk men-validasi hasil analisis yang dilakukan. Kunjungan lapang dilakukan dengan menggunakan beberapa tematik peta, data satelit, dan GPS.

Data spasial vektor yang akan digunakan diantaranya adalah peta topografi dan aksesibilitas. Data topografi yang meliputi ketinggian dan kemiringan lereng akan diperoleh dari data dasar peta rupa bumi (RBI) skala 1:50.000 yang diproduksi oleh Badan Geospasial Indonesia (Bakosurtanal) atau data topografi yang dihasilkan dari hasil pengukuran satelit radar, yaitu Shuttle Radar Topography Mission (SRTM) dan/atau ASTER GDEM (ASTER Global Digital Elevation Model).

\subsection{Analisis Pre-processing Data}

Pre-processing data satelit LAPAN-A3/IPB secara sistematik, yaitu koreksi geometrik dan koreksi radiometrik, perlu dilakukan sebelum data ini dapat dimanfaatkan lebih jauh. Pusat Teknologi Satelit (Pusteksat) LAPAN telah melakukan tahapan preprocessing ini, seperti menggunakan metode Relative Vignetting, Absolute Radiometry dan Image Focusing untuk koreksi radiometrik; dan metode Band Coregistration, Image Jitter Correction dan Direct Georeferencing untuk koreksi geometrik. Namun selain koreksi tersebut, kalibrasi radiometrik sensor diperlukan untuk mengoptimalkan karakteristik fitur spektral dari sensor multispektral imager (MSI) LAPAN-A3/IPB. Kalibrasi radiometrik pada instrument optik remote sensing dapat dilakukan sebelum atau setelah periode peluncuran satelit ke orbit, baik kalibrasi laboratorium, on-board calibration, dan metode vicarious/cross calibration (Chander et al. 2009, Xiong dan Barnes 2006). Kalibrasi sering dilakukan melalui pengukuran reflektan permukaan in situ (surface reflectance) dan kondisi atmosfer, Akan tetapi, data hasil pengukuran spektral secara in-situ dan koefisien kalibrasi radiometrik sensor MSI LAPANA3/IPB tidak tersedia, sehingga pengunaan citra dari intrument (satelit) lain yang telah terkalibrasi, seperti LANDSAT atau MODIS (Huete et al. 2002 dan
Sakamoto et al., 2005) dapat dilakukan untuk menggantikan pengukuran spektral secara in-situ.

Dalam studi ini, metode histogram matching dilakukan terhadap data citra LAPAN-A3/IPB dengan menggunakan citra LANDSAT sebagai referensinya. Metode histogram matching yang menggunakan algoritma umum tradisional histogram matching, atau lebih dikenal Generalized Histogram Matching (GHM). Beberapa scenario yang dipertimbangkan dalam metode ini adalah:

1. Dari data LAPAN-A3/IPB dan LANDSAT, atau Ia dan $\mathrm{Ib}$, dibagi menjadi $\mathrm{k}$ sub-image dari masingmasing. Dari masing-masing sub-image tersebut, local histogram nya dikalkulasi sehingga menghasilkan dua set grafik histogram $A=\left\{a_{i}\right\}_{i=1}^{k}$ untuk citra Ia dan $B=\left\{b_{i}\right\}_{i=1}^{k}$ untuk citra Ib, ai merefer pada bi, $\mathrm{I}=1, \ldots . \mathrm{k}$.

2. Pengukuran distance $d(. . .$.$) antara dua histogram.$ Kami mengasumsikan $\mathrm{d}$ adalah additive, contohnya: untuk dua histogram, a dan b, $d(a, b)=$ $\sum_{i} d(a(i), b(i))$, dimana d(a(i),b(i)) adalah jarak bin-to-bin antara dua set histogram A dan B, dan distance didefinisikan sebagai jumlah jarak dari semua pasangan histogram tersebut:

$$
d(A, B)=\sum_{a i \ni A, b i \ni B} d\left(a_{i}, b_{i}\right)
$$

3. Histogram sub-image A akan menyerupai sedapat mungkin dengan sub-image $B$.

Sebelum dilakukan histogram matching LAPANA3/IPB dan LANDSAT, data citra referensi dipersiapkan dalam bentuk nilai reflectance (bukan digital number/DN). Data LANDSAT yang digunakan dalam 12bit DN dengan resolusi spasial di permukaan $30 \mathrm{~m}$. Nilai DN dikonversi menjadi data radiance melalui kalibrasi menggunakan koefisien gain dan bias yang diperoleh dari metadata citra. Formula perubahan nilai DN menjadi nilai radiance adalah:

$$
R A D=\text { gain } \times D N+\text { offset }
$$

Selanjutnya, nilai radiance diubah menjadi TOA reflectance (Top of Atmosphere) data LANDSAT yang dikalkulasi menggunakan formula sebagai berikut:

$$
T O A=\pi d^{2} \times R A D /(E S U N \times \cos \theta)
$$

dimana $d$ adalah Earth-Sun distance, RAD adalah radiance $\left(\mathrm{w} . \mathrm{m}^{-2} \mathrm{sr}^{-1} \mu \mathrm{m}^{-1}\right)$ dari citra LANDSAT, ESUN adalah rata-rata TOA solar irradiance $\left(\mathrm{w} \cdot \mathrm{m}^{-2} \mu \mathrm{m}^{-1}\right)$, dan $\theta$ adalah solar zenith angle.

\subsection{Normalized Difference Vegetation Index (NDVI)}

Normalized Difference Vegetation Index/NDVI adalah indeks yang menggambarkan tingkat kehijauan suatu tanaman. Indeks vegetasi merupakan kombinasi 
matematis antara band merah dan band NIR (Near-Infrared Radiation) yang telah lama digunakan sebagai indikator keberadaan dan kondisi vegetasi (Lillesand dan Kiefer 1997). Menurut Ryan (1997), perhitungan NDVI didasarkan pada prinsip bahwa tanaman hijau tumbuh secara sangat efektif dengan menyerap radiasi di daerah spektrum cahaya tampak (PAR atau Photosynthetically Aktif Radiation), sementara itu tanaman hijau sangat memantulkan radiasi dari daerah inframerah dekat.

Konsep pola spektral di dasarkan oleh prinsip ini menggunakan hanya citra band merah adalah sebagai berikut:

$$
N D V I=\frac{(N I R-R e d)}{(N I R+R e d)}
$$

dimana, NIR dan Red adalah radiasi inframerah dekat dan merah dari piksel. Nilai NDVI ini berkisar dari -1 (yang biasanya air) sampai +1 (vegetasi cukup rapat).

\subsection{Identifikasi Fase Tanam Padi}

Kondisi fase pertumbuhan tanaman padi pada lahan sawah dapat dideteksi dari perubahan nilai NDVI ( $\triangle$ NDVI). Fase vegetatif ditandai dengan perubahan nilai NDVI yang positif dan fase generatif ditandai dengan perubahan nilai NDVI yang negatif. Kriteria penentuan fase pertumbuhan padi adalah sebagai berikut:

$$
\Delta N D V I=N D V I_{t}-N D V I_{t-1}
$$

(a) Fase dominan air, jika NDVI(t) $\leq 0.19$

(b) Fase bera, jika NDVI(t) > 0.19 dan NDVI(t) < 0.22

(c) Fase vegetatif, jika nilai NDVI $>0$

(d) Fase generatif, jika nilai NDVI $<0$

\subsection{Survey dan Observasi Lapang}

Pengambilan data lapangan di Kabupaten Karawang dilakukan pada tanggal 17-18 Juni 2017, 19 Juli 2017 dan 4-5 Agustus 2017. Data citra resolusi tinggi diambil dengan menggunakan quadcopter drone merk DJI Phantom 3 dan 4 Pro dengan ketinggian terbang 60-80 $\mathrm{m}$. Resolusi data citra yang diperoleh pada ketinggian $80 \mathrm{~m}$ adalah $6 \mathrm{~cm}$ pixel size. Selain pengambilan data citra menggunakan quadcopter drone, dilakukan pula pengukuran nilai reflectance dari tanaman padi menggunakan spectroradiometer.

\section{Hasil dan Pembahasan}

Berdasarkan hasil kajian sebelumnya menggunakan data MODIS selama 15 tahun (Arifin et al., 2016) diperoleh 10 kelas variasi pola tanam yang dominan di Jawa Barat (Gambar 4). Pengkelasan ini cukup untuk menggambarkan variasi pola tanam di lahan sawah. Menurut data Kementerian Pertanian (2015-2016), pembagian waktu tanam (kalender tanam) tahun 2015 di Provinsi Jawa Barat dibagi menjadi dua yaitu musim hujan dan musim kering. Pemulaan tanam di musim hujan dimulai pada bulan Oktober sampai Maret, sedangkan di musim kering dimulai pada bulan April sampai September (Gambar 4a).

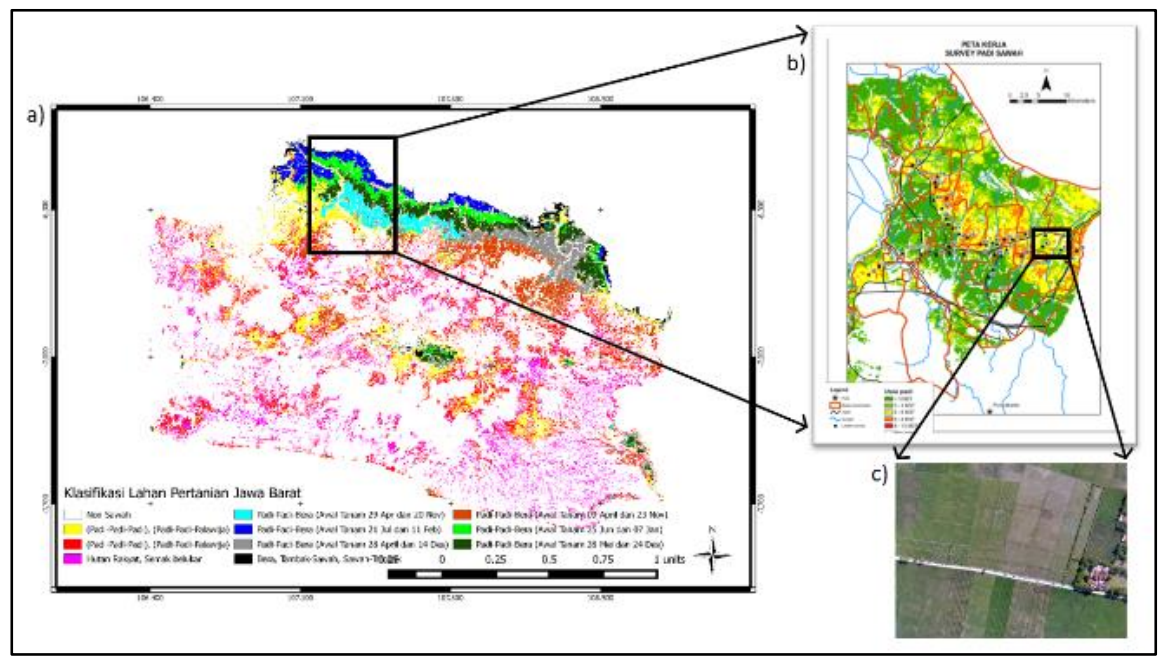

Gambar 4. a) Hasil klasifikasi variasi pola tanam dari penelitian sebelumnya menggunakan metode klasifikasi k-mean (b) Pemetaan fase tanam padi sawah di lokasi penelitian dari data MODIS menggunakan nilai indeks vegetasi, dan c) Variasi fase tanam padi sawah dari data drone high-resolution image yang diamati di lokasi penelitian

Selain hasil kajian diatas, penetapan lokasi pengamatan/observasi lapangan didasarkan pula pada hasil analisis fase tanam padi sawah yang didasarkan pada hubungan nilai indeks vegetasi (NDVI) dan estimasi umur padi sesuai hasil penelitian Pradipta (2012). Hasil estimasi umur padi sawah tersebut digambarkan pada Gambar 4-b. Berdasarkan hasil analisis, terdapat variasi pola tanam campuran dalam satu pixel data MODIS (luas 6.25 ha), sehingga klasifikasi lahan sawah yang direprentasikan oleh pixel tersebut menjadi sulit untuk diidentifikasi pola tanam nya (Gambar 4-c). 


\subsection{Karakterisasi spectral feature LAPAN A3/IPB dan LANDSAT 8 OLI}

Karakterisasi data LAPAN A3/IPB dan LANDSAT 8 OLI ditujukan untuk mengetahui performa sensor yang terpasang pada satelit LAPAN A3/IPB, terutama untuk mendeteksi objek tutupan lahan di lahan pertanian sawah (Gambar 5). Perbandingan nilai spectral LAPAN A3/IPB dan LANDSAT ini dilakukan terhadap beberapa objek pada 4 band yang tersedia, yaitu: band blue, green, red, dan near infra-red (NIR).

Hasil perbandingan data band B, G, R dan NIR dari sensor Lapan A3/IPB dan LANDSAT 8 OLI disajikan pada beberapa gambar di bawah (Gambar 6, 7, dan 8).

Pada gambar diatas dapat dilihat bahwa band Red dan NIR pada sensor MSI LAPAN-A3/IPB memiliki respon yang menyerupai sensor LANDSAT 8 OLI. Performa dua band lainnya yaitu Blue dan Green pada LAPAN-A3/IPB tidak terlalu berkorelasi baik dengan

a)

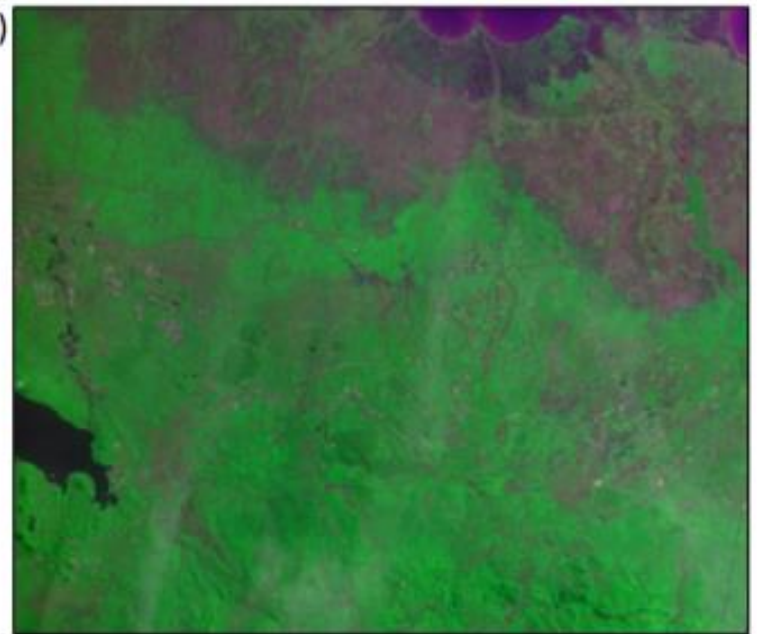

LANDSAT 8 OLI. Hal ini terkait dengan sensitivitas sensor LAPAN-A3/IPB yang ditunjukkan oleh relative spectral response dan rentang nilai panjang gelombang (wavelength) yang dapat ditangkap oleh masing-masing sensor/band (Gambar 9).

Gambar 9 di bawah menunjukkan bahwa panjang gelombang band Red dan NIR pada LAPAN-A3/IPB berada pada kisaran nilai yang cukup terpisah, meskipun kisaran nilai band NIR-nya lebih lebar dibandingkan dengan LANDSAT 8. Karakteristik band Red dan $N I R$ ini mengindikasikan bahwa objek vegetasi dan non-vegetasi dapat dibedakan dengan mudah pada data LAPAN-A3/IPB. Adapun kisaran panjang gelombang pada dua band lainnya, yaitu: band Blue dan Green, agak berhimpitan atau saling silang, sehingga kesulitan untuk membedakan variasi objek non-vegetasi, seperti: air, lahan terbuka (bare) dan lahan terbangun (built-up).

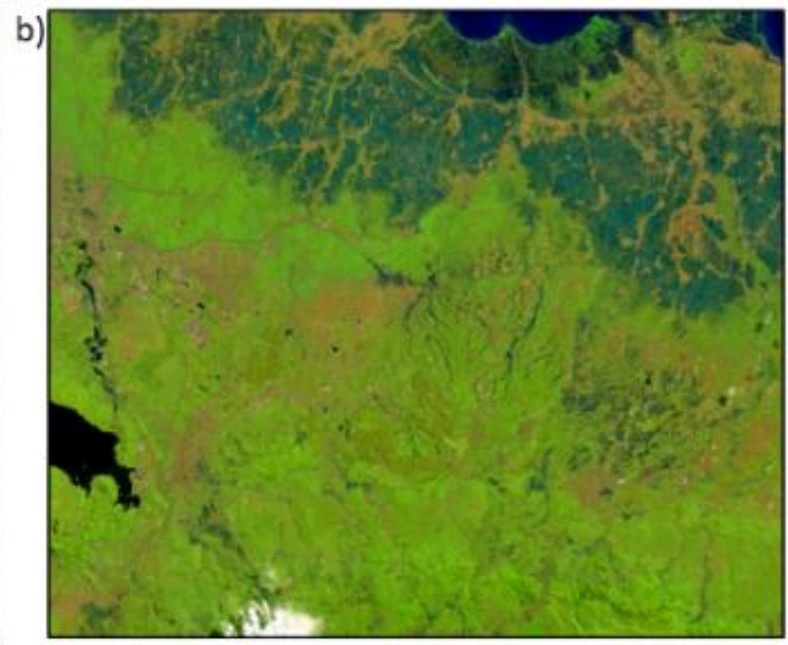

Gambar 5. Data citra LAPAN A3/IPB, b) Data citra LANDSAT 8

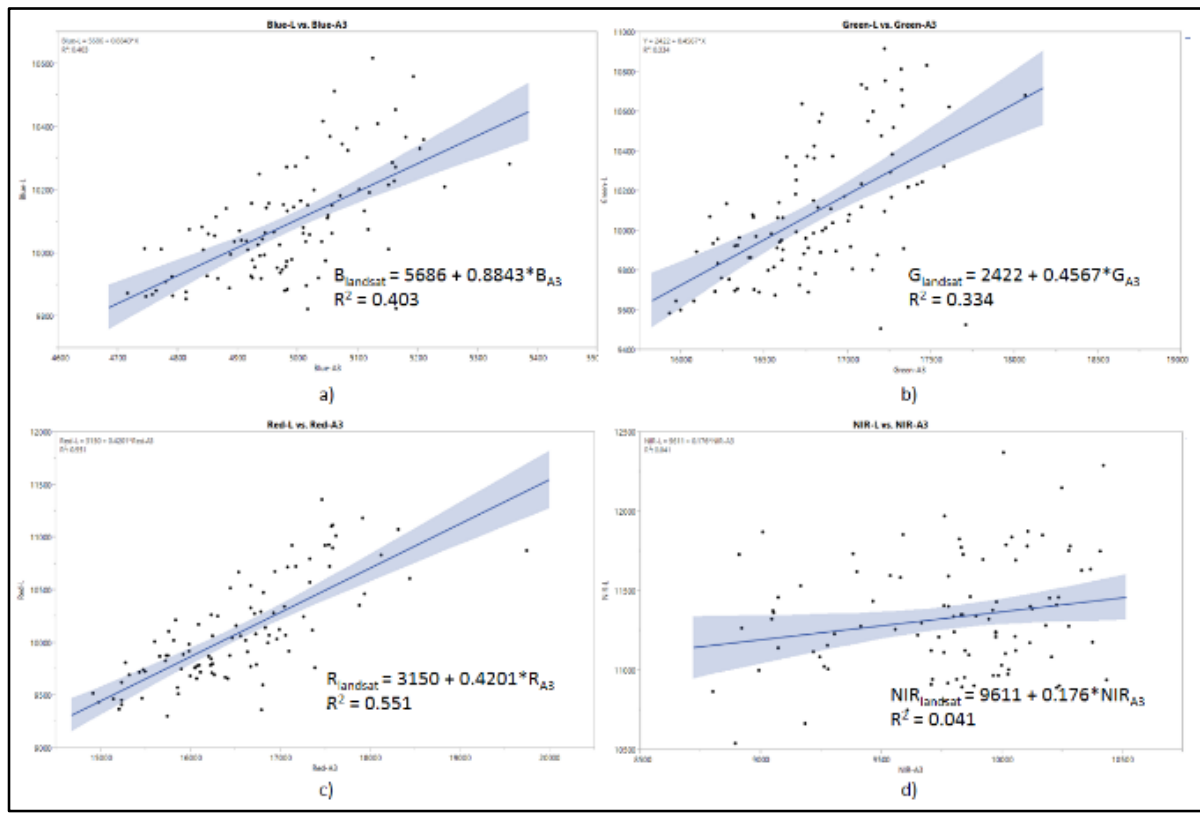

Gambar 6. Perbandingan nilai spectral di fase penggenangan (dominan air) umur $<3$ MST a) Blue, b) Green, c) Red, dan d) NIR 


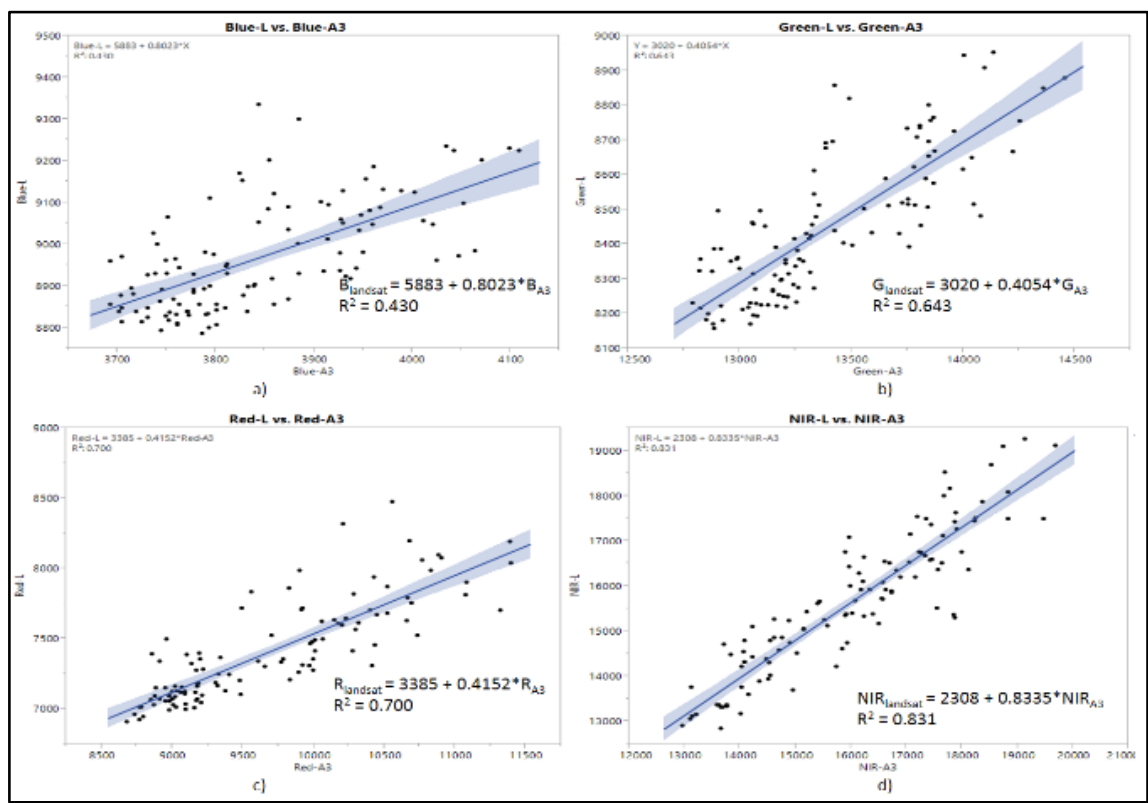

Gambar 7. Perbandingan nilai spectral pada fase vegetative, umur 3-6 MST a) Blue, b) Green, c) Red, dan d) NIR

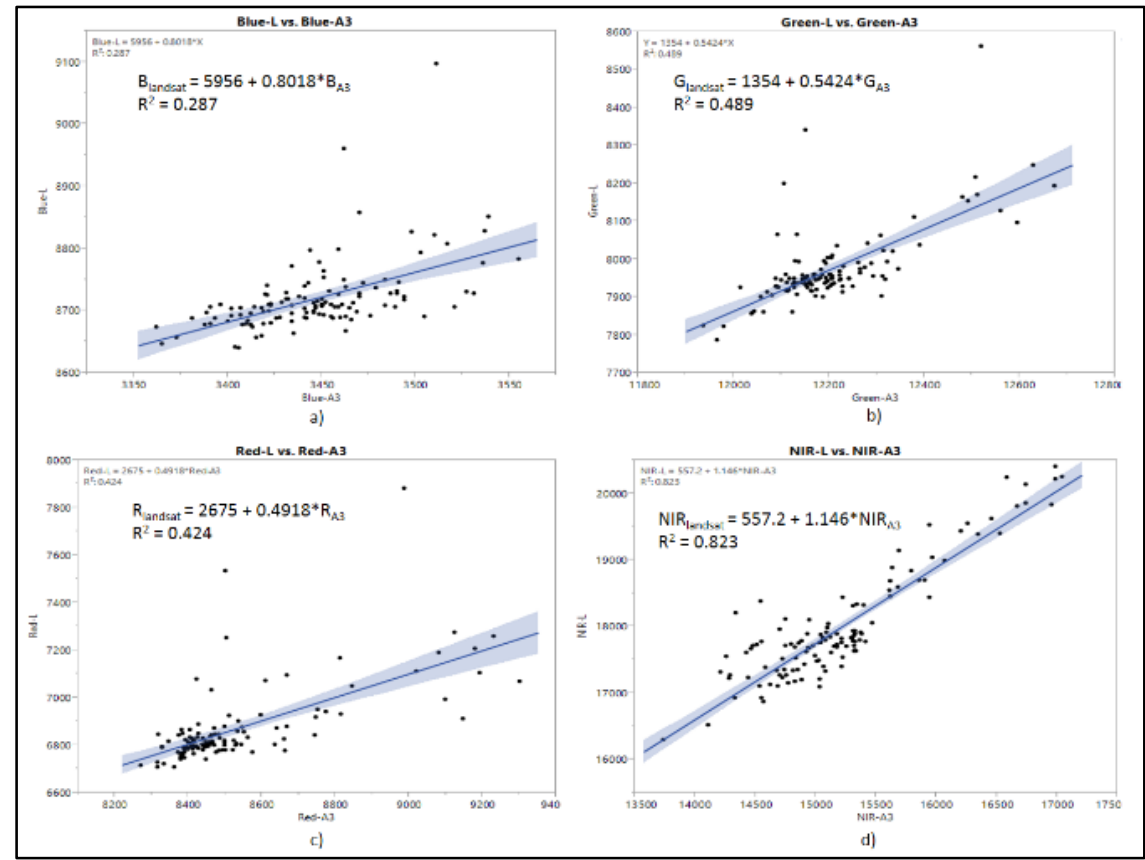

Gambar 8. Perbandingan nilai spectral pada fase vegetative, umur 6-8 MST, a) Blue, b) Green, c) Red, dan d) NIR

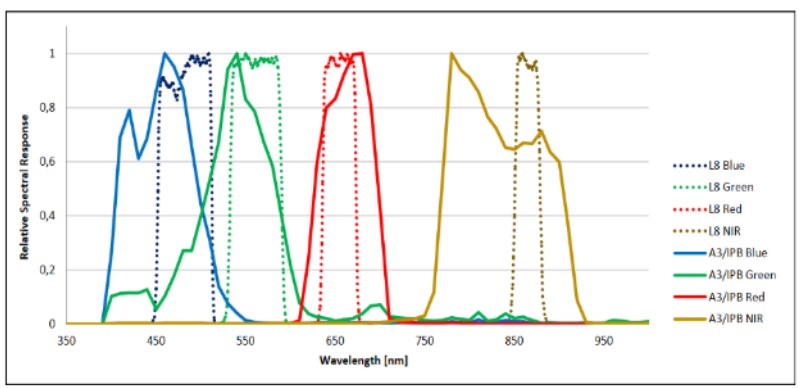

Gambar 9. Perbandingan Relative Spectral Response (RSR) antara LAPAN-A3/IPB dan LANDSAT 8

\subsection{Koreksi Atmosfer Per-Pixel untuk LAPAN-A3/IPB}

Histogram matching adalah metode yang cukup sederhana dan mudah untuk mengoreksi variasi atmosfer yang didasarkan pada manipulasi histogram data sesuai dengan histogram data referensi. Data referensi yang dimaksud adalah data yang telah terkoreksi atmosfer/Top of Atmosphere (TOA) atau diasumsikan memiliki kondisi atmosfer yang ideal. Studi ini menggunakan data LANDSAT 8 OLI (band 2, 3, 4, dan 5) sebagai data referensi dalam koreksi atmosfer untuk LAPAN-A3/IPB. 

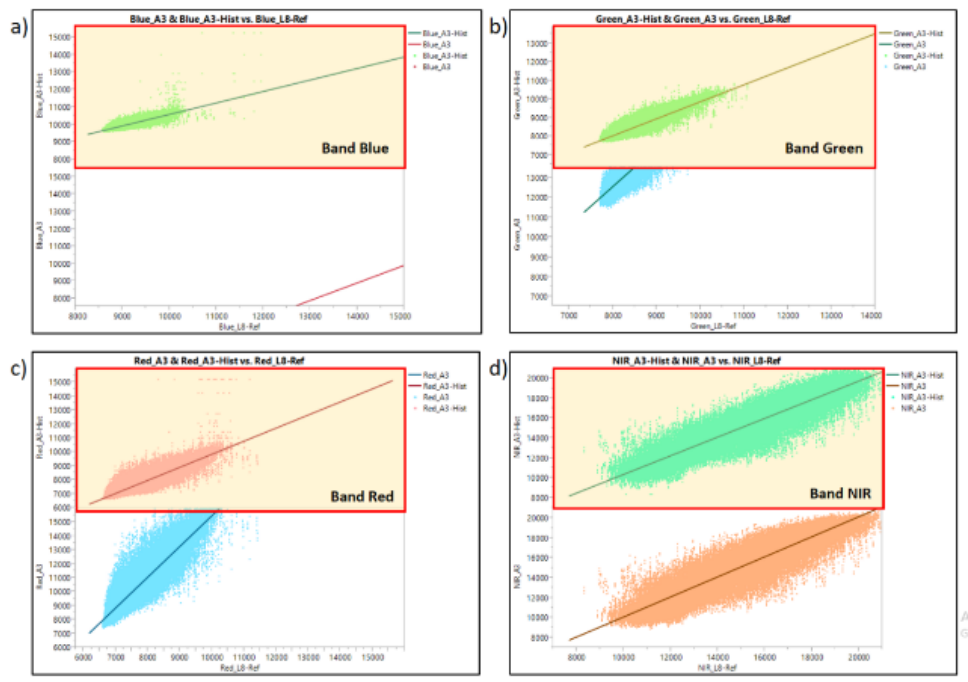

Gambar 10. Hasil histogram matching dari masing-masing band LAPAN-A3/IPB terhadap referensi band LANDSAT 8: a) band Blue, b) band Green, c) band Red dan d) band NIR. Grafik dalam boks garis merah pada setiap band merupakan perubahan distribusi nilai setelah histogram matching dengan menggunakan referensi LANDSAT 8.
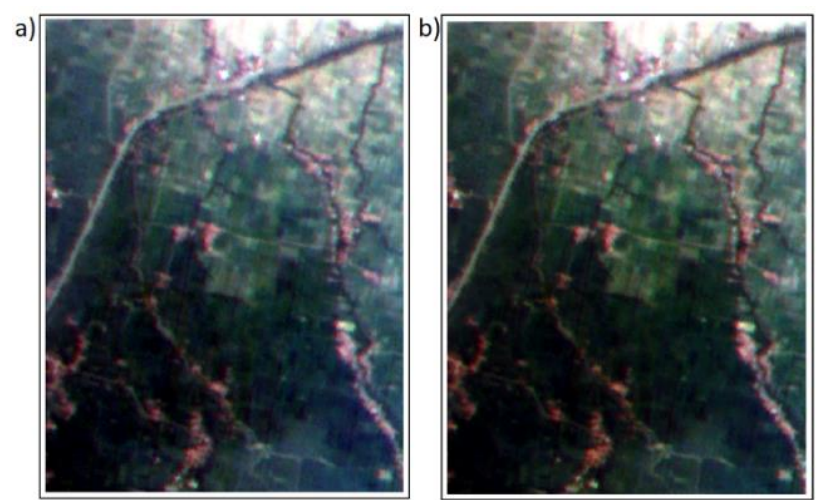

Gambar 11. Citra LAPAN-A3/IPB dengan kombinasi band NIR-R-G: a) Sebelum histogram matching dan b) Setelah histogram matching

Gambar 10 menunjukan bahwa nilai histogram matching sangat signifikan mengubah distribusi nilai pada band Blue dan band Green pada LAPAN-A3/IPB.

Hasil histogram matching pada citra LAPANA3/IPB setelah dilakukan histogram matching dapat dilihat pada Gambar 11. Gambar 12 menunjukkan perbedaan nilai NDVI sebelum dan sesudah dilakukan histogram matching. Sebelum koreksi tersebut terlihat bahwa nilai band Blue LAPAN-A3/IPB berada jauh lebih kecil dibandingkan dengan band Blue LANDSAT 8, sedangkan nilai band Green sebaliknya. Berdasarkan gambar diatas, terlihat bahwa performa nilai band Red LAPAN-A3/IPB sudah cukup baik, meskipun masih relatif lebih tinggi dibandingkan dengan nilai band Red LANDSAT 8. Performa terbaik dari sensor LAPANA3/IPB direpresentasikan oleh band NIR, dimana distribusi nilai band ini sangat mirip menyerupai band NIR dari LANDSAT 8. Perbandingan citra LAPAN-A3/IPB setelah dilakukan proses histogram matching dan LANDSAT 8 dapat dilihat pada Gambar 13.
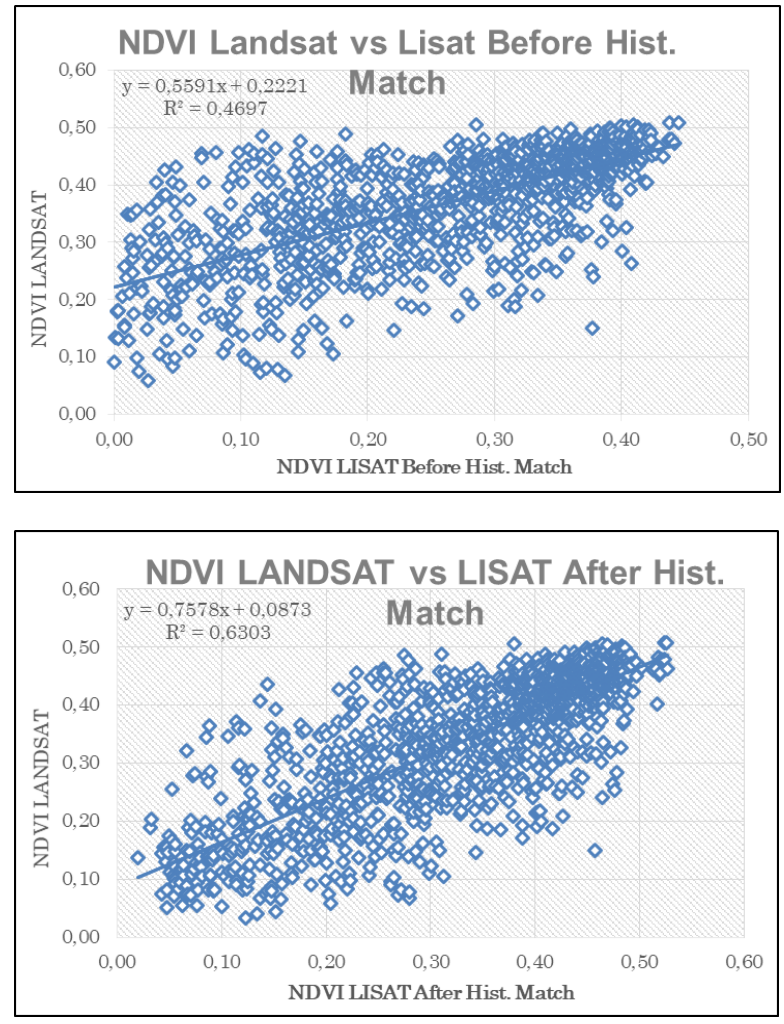

Gambar 12. Perbandingan nilai NDVI data LAPAN-A3/IPB dan LANDSAT 8: a) Sebelum histogram matching, dan b) Setelah histogram matching

\subsection{Kompleksitas Data Citra Satelit vs Data High- Resolution Citra Drone}

Hasil pengambilan data citra resolusi tinggi (highresolution) dengan menggunakan drone dapat dilihat pada Gambar 6. Perbedaan fase tanam di beberapa petak sawah dapat diidentifikasi berdasarkan perbedaan warna yang dihasilkan. Berdasarkan pengamatan di lapangan, dapat diidentifikasi bahwa fase tanam di lokasi pengamatan (specific site) bervariasi dari 2 minggu setelah tanam (MST) hingga 6 MST. 
Perbedaan fase pertumbuhan tanaman padi yang dapat diamati dari data drone-RGB diatas, juga dapat diidentifikasi lebih jelas dari data drone-multispectral. Nilai reflektan yang berbeda dari beberapa petak sawah mengindikasikan perbedaan fase pertumbuhan tanaman padi. Nilai reflektan ini mengambarkan respon spectral

\section{LAPAN A3/IPB}

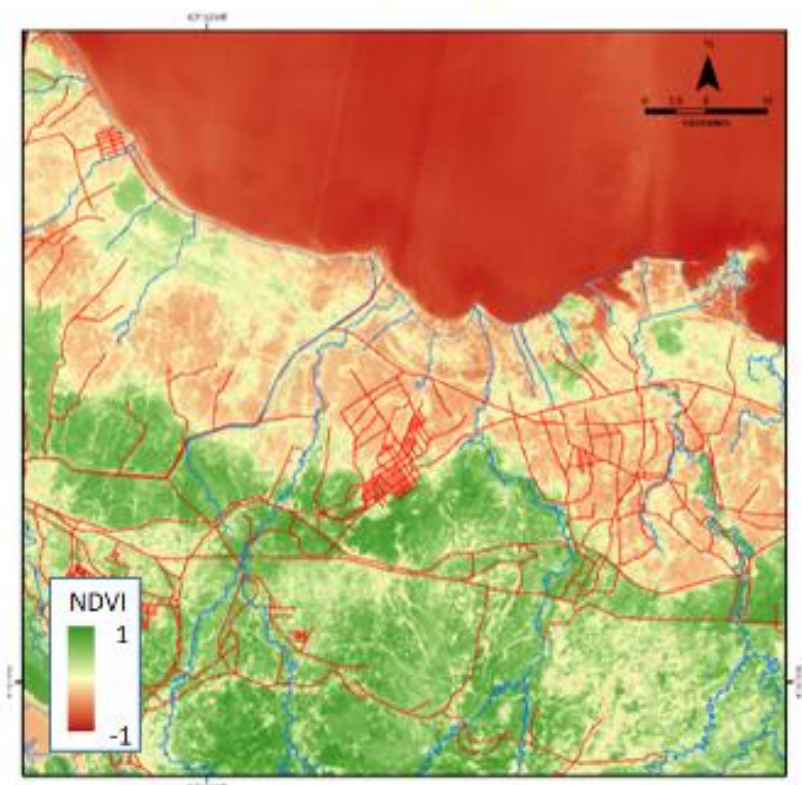

dari objek-objek terhadap sensor band green, red, red edge dan near-infrared (NIR). Hasil akuisisi data citra pada masing-masing band tersebut dan contoh kombinasi band dapat dilihat pada Gambar 14 .

Gambar 13. Perbandingan hasil analisis NDVI untuk menduga fase pertumbuhan tanaman padi: a) LAPAN-A3/IPB dan b) LANDSAT 8

Analisis data pada nilai masing-masing band digunakan untuk membedakan kondisi beberapa fase pertumbuhan tanaman padi. Analisis nilai band dengan menggunakan indeks vegetasi seperti NDVI (Normalized Difference Vegetation Index) dapat digunakan untuk mengestimasi fase pertumbuhan tanaman padi, yang meliputi fase penggenangan, fase penanaman (mulai tanam), fase vegetatif, fase generatif, fase pemanenan, dan fase bera, dan seterusnya. Fase penggenangan ditandai dengan nilai NDVI yang negatif, yang kemudian meningkat menjadi positif pada fase vegetative. Puncak fase vegetative ditunjukkan dengan nilai NDVI positif tertinggi, kemudian, permulaan fase generatif hingga fase pemanenen ditandai dengan perubahan nilai NDVI yang mendekati nilai nol/negatif. Distribusi nilai $N D V I$ pada lokasi pengamatan dapat dilihat pada Gambar 15-b.

Berdasarkan pengukuran spectral menggunakan spectroradiometer di beberapa fase pertumbuhan tanaman padi, diperoleh pola spectral seperti dapat dilihat pada Gambar 16. Diperoleh kisaran nilai NDVI untuk 3 fase pertumbuhan tanaman padi sebagai berikut:
a) 3-4 MST : $0.282<\mathrm{NDVI}<0.335$
b) $5 \mathrm{MST}: 0.336<\mathrm{NDVI}<0.407$

c) 6 MST : $0.408<\mathrm{NDVI}<0.473$

Catatan: MST $\rightarrow$ minggu setelah tanam
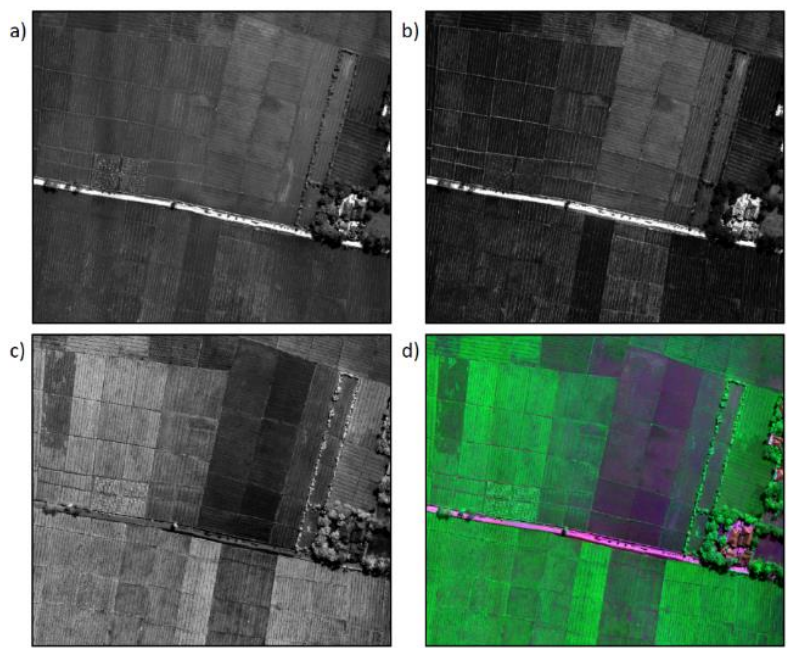

Gambar 14. Hasil perekaman data citra dengan menggunakan drone-kamera multispectral pada beberapa band: a) Green, b) Red, c) NIR dan d) kombinasi band G-RNIR 
a)

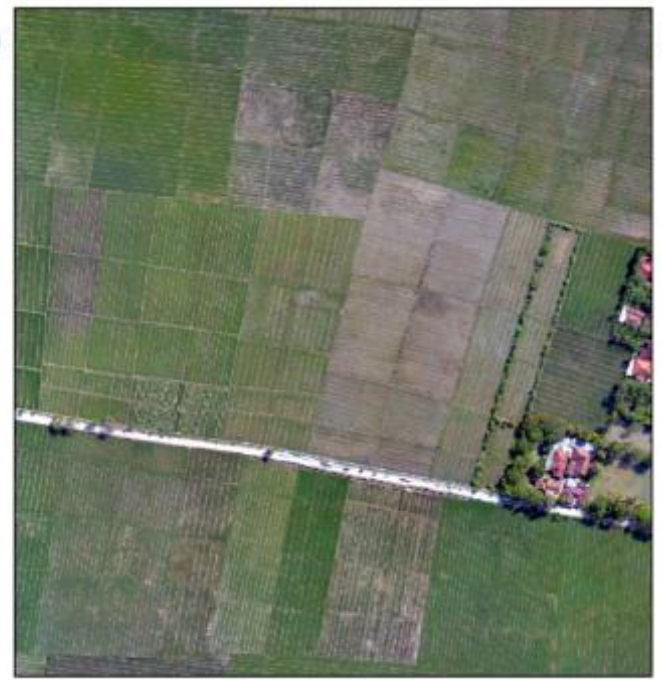

b)

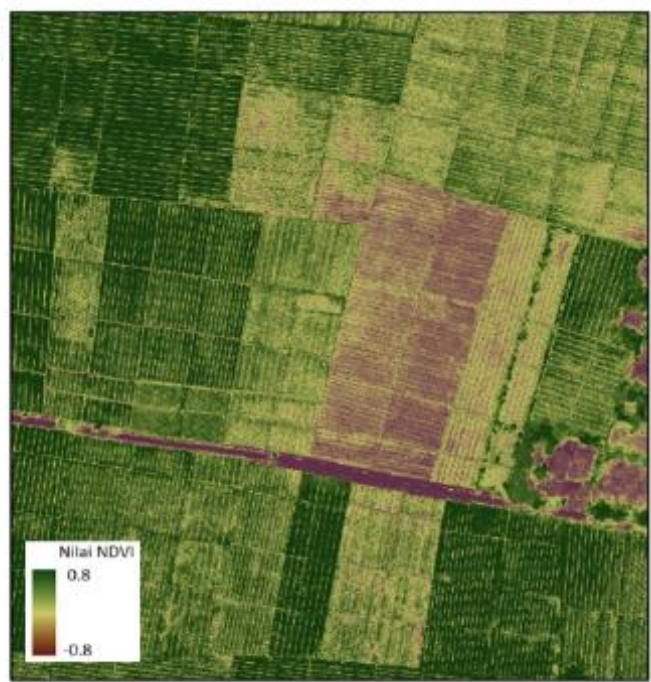

Gambar 15. Data citra resolusi tinggi yang diambil oleh drone; a) Image RGB dan b) NDVI
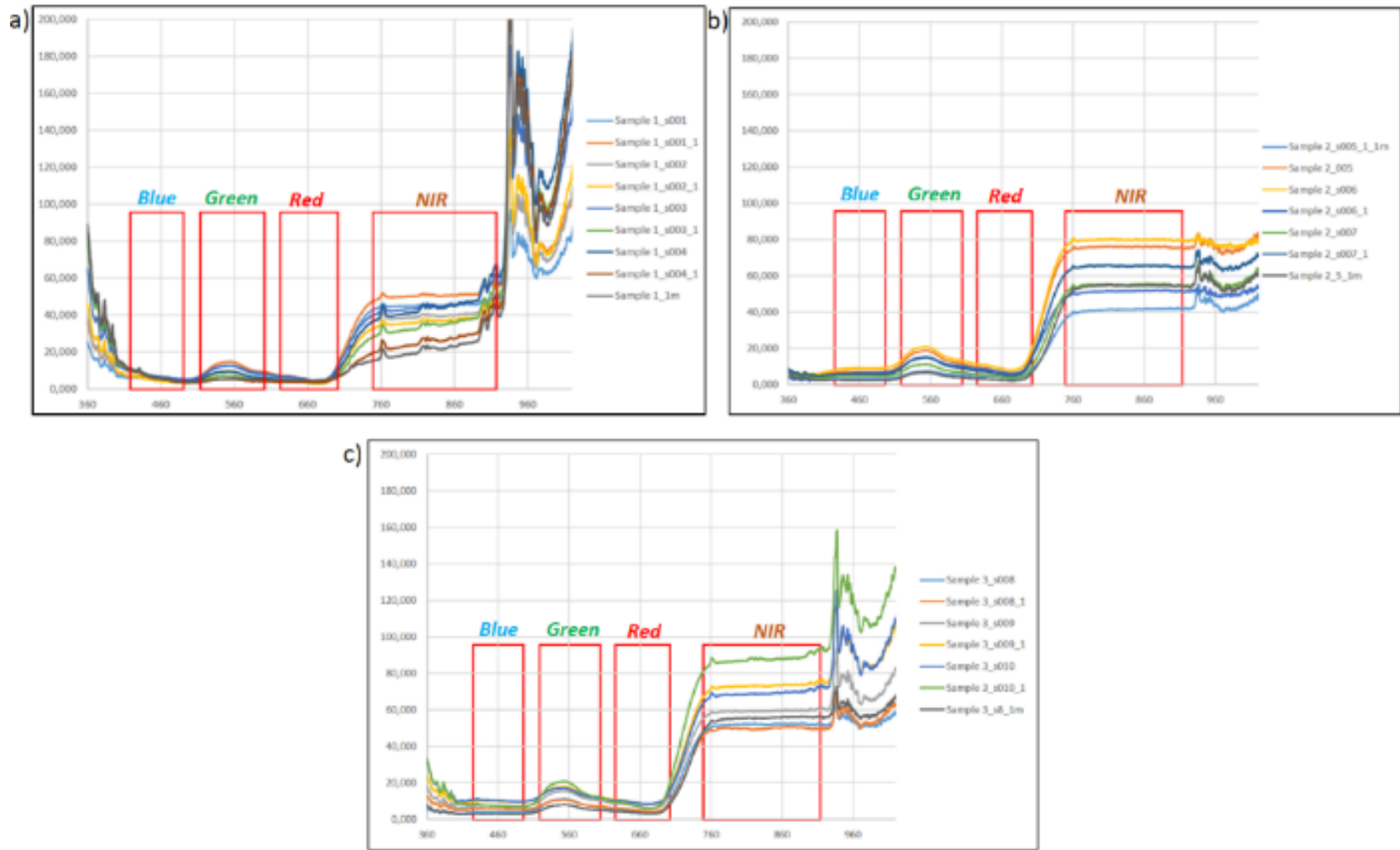

Gambar 16. Hasil Pengukuran spectral menggunakan spectroradiometer di beberapa fase pertumbuhan tanaman padi (fase vegetative): a) 3-4 MST, b) 5 MST, dan c) 6 MST

\section{Kesimpulan}

Karakteristik spectral band Red dan NIR data citra LAPAN A3/IPB memiliki korelasi yang cukup baik dengan band Red dan NIR data citra LANDSAT 8 OLI, terutama untuk mendeteksi lahan sawah pada fase vegetative, dibandingkan dengan band lainnya; band Blue dan Green. Pada semua fase pertumbuhan, band Green dan Red data LAPAN A3/IPB memiliki nilai spectral yang cenderung lebih tinggi dibandingkan dengan nilai spectral data LANDSAT 8 OLI, karakteristik sebaliknya dengan band Blue. Terkait hal ini, perlu dilakukan kajian lebih lanjut melalui pengukuran pixel- based spectroradiometer secara kontinyu untuk mengetahui sensitivitas sensor yang terpasang di satelit LAPAN A3/IPB sebelum data ini dimanfaatkan untuk aplikasi lanjutan termasuk pemetaan lahan sawah dan identifikasi fase pertumbuhan padi sawah.

Pengamatan dan pengukuran nilai spectral dengan menggunakan spectroradiometer perlu dilakukan secara berkala (mulai dari musim tanam ke I) untuk mengetahui dinamika perubahannya terkait dengan fase pertumbuhan padi di lahan sawah. Untuk lahan sawah, pengukuran nilai spectral ini perlu dilakukan setiap 8-16 hari sekali. 
Pra-pengolahan data citra (image pre-processing) perlu dilakukan untuk memperoleh hasil karakterisasi data LAPAN A3/IPB yang lebih baik. Selanjutnya, perlu dikembangkan algorithma atau metode yang sesuai untuk melakukan koreksi geometrik dan koreksi atmospheric data LAPAN A3/IPB.

\section{Ucapan Terima Kasih}

Penelitian ini didukung oleh Direktorat Jenderal Pendidikan Tinggi, Kementerian Riset, Teknologi, dan Pendidikan Tinggi (Kemenristekdikti) untuk tahun anggaran 2017 dibawah skema Penelitian Unggulan Perguruan Tinggi / Penelitian Institusi (PUPT/PI).

\section{Daftar Pustaka}

[1] Agus, F., 2004. Konversi dan Hilangnya Multifungsi Lahan Sawah. Balai Penelitian Tanah, Bogor.

[2] Arifin, M.T., Liyantono, Y. Setiawan, A. Fatikhunnada, 2016 Processing System of MODIS Data for Monitoring the Changes of Paddy Field. Procedia Environmental Sciences 33, pp. 3013.

[3] Chander, G., B.L. Markham, D.L. Helder, 2009. Summary of Current Radiometric Calibration Coefficients for Landsat MSS, TM, ETM+, and EO-1 ALI Sensors. Remote Sensing of Environment 113(5), pp. 893-903.
[4] Huete, A., K. Didan, T. Miura, E.P. Rodriguez, X. Gao, L.G. Ferreira, 2002. Overview of the radiometric and biophysical performance of the MODIS vegetation indices. Remote Sensing of Environment 83, pp. 195-213.

[5] Lillesand, T.M. dan R.W. Kiefer, 1997. Penginderaan Jauh dan Interpretasi Citra. Dulbahri, Prapto Suharsono, Hartono, Suharyadi, Penerjemah. Terjemahan dari: Remote Sensing and Image Interpretation. Gajah Mada University Press, Yogyakarta.

[6] Pradipta, D., 2012. Analisis Data Time Series NDVI-SPOT Vegetation Untuk Tanaman Padi (Studi Kasus: Kabupaten Karawang). Institut Pertanian Bogor, Bogor.

[7] Ryan, L., 1997. Creating a Normalized Difference Vegetation Index (NDVI) image Using MultiSpec. University of New Hampshire.

[8] Sakamoto, T, M. Yokozawa, H. Toritani, M. Shibayama, N Ishitsuka, H. Ohno, 2005. A crop phenology detection method using time-series MODIS data. Journal of Remote Sensing of Environment 96, pp. 366-374.

[9] Setiawan, Y., and K. Yoshino, 2013. Detecting land use change from seasonal vegetation dynamics in regional scale with MODIS EVI 250 m time-series imagery. Journal of Land Use Science 7 (1), pp. 1-27.

[10] Setiawan, Y., K. Yoshino, and L.B. Prasetyo, 2014. Characterizing the dynamics change of vegetation cover on tropical forestlands using $250 \mathrm{~m}$ multi-temporal MODIS EVI. International Journal of Applied Earth Observation and Geoinformation 26, pp.132-144.

[11] Xiong, X., W. Barnes, 2006. MODIS Calibration and Characterization. In: Qu J.J., Gao W., Kafatos M., Murphy R.E., Salomonson V.V. (eds) Earth Science Satellite Remote Sensing. Springer, Berlin, Heidelberg. 